\title{
Economic motivation of households to undertake private precautionary measures against floods
}

\author{
H. Kreibich ${ }^{1}$, S. Christenberger ${ }^{2}$, and R. Schwarze $\mathbf{e}^{2,3}$ \\ ${ }^{1}$ Helmholtz Centre Potsdam German Research Centre for Geosciences (GFZ), Section Hydrology, Potsdam, Germany \\ ${ }^{2}$ Leopold-Franzens-University of Innsbruck (UIBK), Faculty of Economics and Statistics, Innsbruck, Austria \\ ${ }^{3}$ Climate Service Center - CSC, Hamburg, Germany
}

Received: 5 May 2010 - Revised: 2 November 2010 - Accepted: 11 November 2010 - Published: 3 February 2011

\begin{abstract}
Flood damage is on the increase due to a combination of growing vulnerability and a changing climate. This trend can be mitigated only through significantly improved flood risk management which, alongside the efforts of public authorities, will include improvements in the mitigation measures adopted by private households. Economically "reasonable" efforts to self-insure and self-protect should be expected from households before the government steps in with publicly-funded relief programmes. To gain a deeper understanding of the benefits of households' precautionary measures, telephone interviews with private home owners were conducted in the Elbe and Danube catchments in Germany after the floods of 2002 and again after the floods in 2005 and 2006. Only detached, solid single-family houses were included in this study, which is based on 759 interviews. In addition, market-based cost assessments were solicited based on a "model building". Expert interviews and a literature review - including catalogues and price lists for building materials and household appliances were used as back-up information for the cost assessments. The comparison of costs and benefits shows that large investments, such as building a sealed cellar, are only economically efficient if the building is flooded very frequently, that is, if it is located in a high flood risk area. In such areas it would be preferable in economic terms not to build a new house at all - or else to build a house without a cellar. Small investments, however, such as oil tank protection, can prevent serious damage at low cost. Such investments are still profitable even if the building is flooded every 50 years or less on average. It could be argued that these low-cost measures should be made mandatory through
\end{abstract}

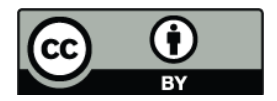

Correspondence to: $\mathrm{H}$. Kreibich (kreib@gfz-potsdam.de) the enforcement of building codes. Financial incentives built into insurance contracts coupled with limits set on governmental relief programmes would provide an economic motivation for people to invest in precautionary measures.

\section{Introduction}

Recent floods in Germany have caused high economic damages. For example, the 1993 and 1995 floods in the Rhine catchment area caused total damages of 810 million $€$, the 1997 flood on the Odra river lead to damages of 330 million $€$, the Whitsun flood of 1999 in the Danube catchment caused damages of 412 million $€$, the damages caused within Germany by the extreme flood event of August 2002 in the Elbe and Danube catchment amounted to 11.6 billion $€$ (Kron, 2004), while the August 2005 flood in the Danube catchment resulted in losses of 189 million $€$ in the federal state of Bavaria alone (LfU Bayern, 2006). The 2006 flood in the Elbe catchment caused damages of approximately 100 million $\$$ (Munich Re, 2009). The amount of damages arising from the 2010 flood in the Oder, Neisse and Elbe catchments in Germany has not yet been calculated. It is expected that flood damages will rise due to a combination of an increase in vulnerability, mainly trough wealth accumulation in flood plain areas, changes in the terrestrial system, e.g., land cover changes, river regulation and a changing climate (e.g., Kundzewizc et al., 2005; Crichton, 2008). A variety of conceptions and definitions of "vulnerability" exist and there is no widely agreed understanding of this term within the academic community (Thywissen, 2006). This study adopts the natural sciencesoriented conception which defines risk as hazard multiplied by vulnerability (e.g., UNDP, 2004), where vulnerability

Published by Copernicus Publications on behalf of the European Geosciences Union. 
comprises two elements: exposure and susceptibility (Merz and Thieken, 2004; Department of Human Services, 2000). Consequently, a significant cause of rising flood damages are increased house values as well as an increase in residential and commercial developments in flood-prone areas, leading to greater exposure for private households. In industrialised countries, this trend is due to the growing attraction of living near waterfronts, an efficient transport infrastructure and the proximity of urban developments to flood risk areas. In Germany, for example, communities with more than 5,000 inhabitants are twice as likely to be located near a river (Borchert, 1992). Additionally, climate change may also be responsible for an increase in flood damages in some regions. In a Germany-wide study, Petrow and Merz (2009) identified spatially and seasonally coherent trend patterns for the period 1951-2002 and suggested that the observed changes in flood behaviour were climate-driven. In contrast to this, Mudelsee et al. $(2003,2004)$ identified a decrease in winter flooding in their analysis of long-term discharge records at the Dresden gauge on the Elbe river, while summer flooding showed no trend at all. On the basis of existing empirical trend studies and scenario-based simulation studies, it must be concluded that flood hazards are currently changing and that larger changes are likely in the future. However, it is difficult to establish a precise estimate of the impact of climate change on extreme flood events (e.g., Smith, 1999; Schreider et al., 2000; Hall et al., 2005; Svensson et al., 2006). At present and with regard to the near future, the observed and projected significant increase in flood damages is driven largely by social factors, specifically increased exposure (Barredo, 2009; Feyen et al., 2009; Hall et al., 2003).

The trend towards increasing flood damages can be mitigated only through significantly improved flood risk management which, in addition to efforts undertaken by public authorities such as technical flood protection measures and increased natural retention, will also include improvements in the mitigation efforts adopted by private households (Hayes, 2004; Wynn, 2004). Risk reduction activities by individuals include precautionary measures taken in and around exposed buildings, preparatory measures such as collecting information about flood risk and flood protection, participation in neighbourhood help, or buying flood insurance. The following precautionary measures, relating specifically to buildings, serve significantly to mitigate damages in flood-prone areas (ICPR, 2002; ABI, 2003; Kreibich et al., 2005):

- building without a cellar,

- adapting the building structure,

- protecting properties using water barriers,

- safeguarding from hazardous substances, e.g., preventing oil contamination.
Buildings without cellars are generally less expensive to construct and are less affected by flooding, particularly in cases where only low water levels occur, e.g., during groundwater flooding (Kreibich and Thieken, 2008). However, they also entail opportunity costs in the form of lower housing quality. Building a structurally flood resistant house, e.g., using a specially stabilised foundation to protect against drift or buoyancy (i.e., lifting force) or sealing the cellar to make it waterproof, implies a considerable outlay. Moreover, these measures may fail, especially during extreme flood events (MURL, 2000). Steel frame and brick buildings tend to be less susceptible to collapse than other materials, and waterproof drywalls will hold up over extended periods of heavy inundation (USACE, 1996). Generally speaking, improving the stability of a building mitigates the damage caused by buoyancy, water pressure and erosion, and may prevent free-standing elements from being washed away. Mobile water barriers are another way to protect properties against inundation, but in order to be effective they need a prior flood warning and time to be set up. The effectiveness of sandbag barriers also depends on the number of rows and the duration of the flood (Reeve and Badr, 2003). A detailed description of alternatives to non-reusable sandbags is provided by Bowker (2002). A further important measure is to ensure the secure storage of oil and other hazardous substances, e.g., in flood-proof fuel oil tanks (ICPR, 2002). Tanks may float when the flood water level rises, and they may also be damaged by water pressure. Containers must, therefore, be tested to ensure that they are secure against buoyancy, and all openings (ventilation fittings, filler plugs) must have watertight closures. Damage from oil contamination is often not confined to a person's own home, but may also affect neighbouring buildings. In Germany, the federal states have laws stipulating that oil heating systems, including oil tanks, have to be flood-proofed within flood risk areas (e.g., VAwS-Baden-Württemberg, 2005; VAwSHessen, 2006; VAwS-Bayern, 2008). Other precautionary measures available to individuals are described, for instance, in Holub and Hübl (2008), BMVBW (2002), Environment Agency (2003a, b), FEMA (1998a, b) and USACE (1995, 1996).

Taking precautionary measures, prior to any cost-benefit calculus, demands self-reliant behaviour on the part of the individuals potentially affected. Raschky (2008) highlights the effects on human behaviour of the institutional framework and the incentives it sets. There are few laws (e.g., building codes) requiring homeowners to take precautionary measures: most measures are voluntary (Heiland, 2002). Previous studies have shown that experience of flooding is a significant factor in motivating people to take voluntary precautionary measures (Grothmann and Reusswig, 2006; Siegrist and Gutscher, 2006, 2008; Thieken et al., 2007). For instance, it has been shown by Smith (1981) and Wind et al. (1999) that damage is reduced significantly only in cases where people have had frequent and recent experience 
Table 1. Flood damage surveys: computer-aided telephone interviews with private households affected by flooding.

\begin{tabular}{|c|c|c|c|}
\hline Characteristics & & Surveys & \\
\hline Date of survey: & April and May 2003 & November and December 2006 & August and September 2007 \\
\hline Region(s): & \multicolumn{2}{|c|}{ Elbe and Danube catchments in Germany } & City of Dresden \\
\hline Flood(s): & 2002 & 2005 and 2006 & $1967-2007$ \\
\hline $\begin{array}{l}\text { Number of household } \\
\text { interviewed: }\end{array}$ & 1697 & 461 & 454 \\
\hline $\begin{array}{l}\text { Number of detached, } \\
\text { single-family } \\
\text { houses (with cellar): }\end{array}$ & $615(472)$ & $113(97)$ & $31(30)$ \\
\hline Reference(s): & Thieken et al. (2007) & $\begin{array}{l}\text { Kreibich and Thieken (2008), } \\
\text { Kreibich et al. (2010) }\end{array}$ & Kreibich et al. (2009) \\
\hline
\end{tabular}

of flooding. In addition to recent flood experience, awareness of living in a flood-prone area seems to be another decisive factor in taking precautionary measures at home (Kreibich et al., 2005). Moreover, people tend to take private precautionary measures only if they are informed of the possibility and believe in the effectiveness of the measures described (Grothmann and Reusswig, 2006). Ultimately, from an economic point of view, individuals need financial incentives before they will invest in selfprotection. Such incentives can be provided either through appropriately worded insurance contracts (Kleindorfer and Kunreuther, 1999; Botzen et al., 2009; Holub and Fuchs, 2009) or else through government finance schemes or aid geared towards enhancing self-reliance. The efficiency of spending, measured by the cost-benefit ratio, is an important benchmark for establishing what constitutes "reasonable" self-protection measures for households engaging in flood risk mitigation efforts. The objective of this study is to quantify specifically the benefits and costs of precautionary measures at household level and to analyse how this knowledge ties into people's economic motivation to take precautionary measures against floods. Only the mitigation of direct economic losses is taken into account; the potential effects of precautionary measures on indirect and intangible damages are not addressed.

\section{Data and methods}

In order to discover the benefits of private precaution in terms of averted flood damages, telephone interviews were conducted with private households in the Elbe and Danube catchments in Germany after the floods of 2002 and again after the floods of 2005 and 2006 (Thieken et al., 2007; Kreibich and Thieken, 2008; Kreibich et al., 2010) and, particularly, in the city of Dresden in August and September 2007 (Kreibich et al., 2009; Table 1). Lists were compiled of all the streets affected with the help of information from local authorities (e.g., personal communication with the administrative districts affected and with the city of Dresden), flood reports or press releases, as well as with the help of flood masks derived from radar satellite data (DLR, Centre for Satellite Based Crisis information, www.zki.caf. dlr.de). This provided the basis for generating buildingspecific random samples of households. Computer-aided telephone interviews were conducted using the VOXCO software package (www.voxco.com). The SOKO institute for social research and communication (www.soko-institut. de) conducted the interviews in April and May 2003 and in September 2007. The Explorare market research institute (www.explorare.de) conducted the interviews in November and December 2006. In most cases, the person in the household with the best knowledge of the flood damage was interviewed. The first phase of the survey after the 2002 flood resulted in 1697 completed interviews. The second phase in 2006 resulted in 461 interviews, and the survey in the city of Dresden resulted in 454 completed interviews with private households affected by flooding (Table 1). All the questionnaires addressed, among other things, the following topics: precautionary measures, flood parameters (e.g., contamination, water level), building characteristics and flood damage to buildings and contents. Building damage included all costs associated with repairing the damage to the building structure, such as plastering, replacing broken windows and repairing the heating system. Contents damage included all costs incurred through repairing or replacing damaged contents, such as domestic appliances, telephone and computer systems and furniture. The questionnaire contained detailed questions addressing not only total damage but also the area affected per storey, the damage ratio, the type and amount of the most expensive item damaged, and the type and costs of all building repairs and all expensive domestic appliances affected. This generated the most accurate information 
Table 2. Model building for costing.

\begin{tabular}{ll}
\hline Building type & $\begin{array}{l}\text { Detached, solid } \\
\text { single-family house with } \\
\text { and without cellar }\end{array}$ \\
\hline Property area (./. river adjacent) & $750 \mathrm{~m}^{2}(10 \mathrm{~m})$ \\
Floor plan & $10 \mathrm{~m} \times 14 \mathrm{~m}$ \\
Cellar area & $65 \mathrm{~m}^{2}$ \\
Thickness of base plate & $25 \mathrm{~cm}$ \\
Thickness of exterior walls & $25 \mathrm{~cm}$ \\
Thickness of cellar ceiling & $20 \mathrm{~cm}$ \\
Ceiling height & $2.50 \mathrm{~m}$ \\
Cellar windows & 4 \\
Soil properties & Clay \\
\hline
\end{tabular}

possible about the extent of damage, avoiding a strategic response bias. Since many people claimed their damages either from government funds or from their insurers, the damage estimates are believed to be reliable. This was also confirmed by a comparison of the damage data collected after the 2002 flood with official damage data from the Saxon Bank of Reconstruction (Sächsische Aufbaubank), which was responsible for administering governmental disaster assistance after the 2002 flood in the federal state of Saxony (Thieken et al., 2005).

Only detached, solid, single-family houses were included in this analysis of the benefits and costs of private precautionary measures. This selection resulted in 759 datasets (Table 1). The homes' median total area was $140 \mathrm{~m}^{2}$ (mean: $157 \mathrm{~m}^{2}$ ) and the median area of the surrounding plot was $750 \mathrm{~m}^{2}$ (mean: $1033 \mathrm{~m}^{2}$ ). Of these buildings, $599 \mathrm{had}$ a cellar and 160 were built without a cellar. The median cellar area was $65 \mathrm{~m}^{2}$ (mean: $68 \mathrm{~m}^{2}$ ). These median values were used to develop the "model building" for cost calculations (Table 2). The buildings without a cellar were taken into account only for the purpose of investigating the measure "building without a cellar" (Sect. 3.2.1); for all the other measures, only the single-family homes with a cellar were analysed.

Drawing on the approach used by Kreibich et al. (2005), damage reduction due to precautionary measures was assessed by comparing actual damage cases where the specific measure was taken with cases where the specific measure was not taken, regardless of other measures. Cases of damage where only the cellar was affected were separated from the cases where the ground floor was also affected, in order to take into account the severity of the inundation.

The cost calculations were based on the following "model building": a detached, solid single-family house with a total area of $140 \mathrm{~m}^{2}$ and a cellar area of $65 \mathrm{~m}^{2}$, located on a plot of $750 \mathrm{~m}^{2}$ (for details see Table 2).
Cost calculations were made on the basis of precautionary measures being implemented during the construction phase, i.e., the cost figures are for new buildings only. The cost calculations are based on tendered construction bids, expert interviews and a literature review, including catalogues and price lists for building and household appliances. The economic efficiency of the measures is calculated by means of a benefit-cost ratio, where the benefit of a measure during its total life-time is related to its total costs, including investment and maintenance. A benefit-cost ratio above one means that the benefits are greater than the costs and the measure is efficient. Since benefits and costs occur at different times, they are homogenised with an interest rate for a common reference date (here the end date). Two interest rates are used here: $3 \%$, which is recommended for flood protection measures by the German Working Group on water issues of the Federal States and the Federal Government (LAWA, www.lawa.de), and $4 \%$, which is the long-term market rate.

Benefit-cost ratios are calculated for two different water depths, namely, flood situations where only the cellar is affected and situations where the ground floors are also affected. Additionally, three different hazard zones (flood frequencies) are taken into account: buildings which are affected by flooding once a year, buildings which are affected once in 10 years and buildings affected once in 50 years.

\section{Results and discussion}

\subsection{Economic motivation behind households' precautionary measures}

From a microeconomic point of view, households' decision to self-protect against risky events is an optimisation calculation. Ehrlich and Becker (1972) were the first to formalise this decision in an abstract model setting. Transposed into an environment of natural risks, this model would appear as depicted in Fig. 1. Figure 1 shows a household's decision to utilize wealth in different states of nature - with and without a natural hazard occurring. Let W1 denote the "state of nature" without flooding and let W2 be the "state of nature" where the damage-causing natural event occurred. Wealth can be shifted between states of nature by means of precautionary measures taken. For example, the (efficient) amount of private precaution $\left(\mathrm{X}^{*}\right)$ can be seen as a spending of wealth in the "state of nature" of no flooding $\left(\mathrm{W}_{1}\right)$ into the "state of nature" of a flood occurring $\left(\mathrm{W}_{2}\right)$. The household is saved from damages in state 2 (flooding) by a spending of wealth in state 1 (no flooding) for precautionary purposes. The efficient shift of wealth between states of nature - or, in other words, the efficient spending on precaution $\left(\mathrm{X}^{*}\right)$ - is defined by the damage avoided $\left(\mathrm{L}-\mathrm{L}^{*}\right)$ relative to the spending of $\mathrm{X}^{*}$. Let $\mathrm{W}$ be the wealth that is 


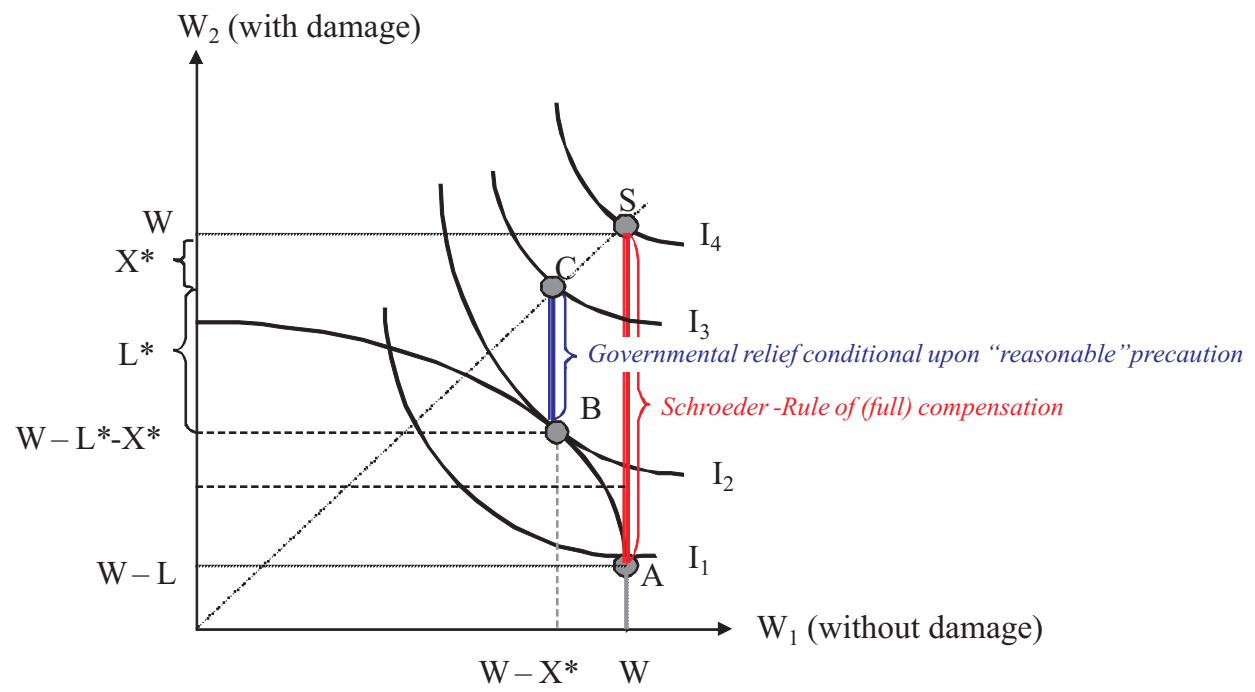

Fig. 1. Basic economic model of precaution and governmental relief relating to damages caused by natural hazards.

available to the household in both states of nature (say, its annual income). $\mathrm{X}^{*}$ is a spending of wealth in the "state of nature" of no flooding (W1) to protect wealth in the "state of nature" of a flood occurring (W2). It mitigates the damages which would occur without any private precaution (L) to the level of flood protection $\left(\mathrm{L}^{*}\right)$. Thus, the household achieves a state of wealth of W-L* $-\mathrm{X}^{*}$ in the "state of nature" of a flood occurring. This is an improvement to the situation without precaution (W-L). For this, the household has to spend precautionarily $\mathrm{X}^{*}$, i.e., it has to accept a lower level of wealth $\left(\mathrm{W}-\mathrm{X}^{*}\right)$ in the "state of nature" of no flooding as well. The efficient substitution of wealth in the situation without damages to the situation with damages is shown in Fig. 1 as the transition from point $\mathrm{A}$ to point $\mathrm{B}$. Thus, the curve through $\mathrm{A}$ and $\mathrm{B}$ shows the possibilities of transforming spending for precaution into saved damages (transformation curve). The ultimate choice of precautionary measures taken by the household is made according to the goal of maximizing household utility (U). The achievable levels of utility are depicted by the convex indifference curves, which could be seen as level curves of utility. Indifference curves, in fact, mark combinations of wealth in both "states of nature" (with and without flooding), which allow the same level of utility (U). Therefore, higher indifference curves show higher levels of utility, i.e., $\mathrm{U}\left(\mathrm{I}_{3}\right)>\mathrm{U}\left(\mathrm{I}_{2}\right)>\mathrm{U}\left(\mathrm{I}_{1}\right)$.

Obviously, the efficient amount of precaution $\left(\mathrm{X}^{*}\right)$ raises the utility of households (from $\mathrm{U}\left(\mathrm{I}_{1}\right)$ to $\mathrm{U}\left(\mathrm{I}_{2}\right)$ ). However, a misplaced promise of complete governmental relief after natural disasters - as had been given, for example, by former German Chancellor Schroeder after the 2002 flood on the river Elbe in his aid policy guidance 'that nobody shall be worse off after the flood - raises recipients' utility levels to a higher level still, $\mathrm{U}\left(\mathrm{I}_{3}\right)$, while at the same time disincentivising any precautionary efforts and any self-reliant behaviour by the population potentially affected (in the sense of Raschky, 2008). An incentive-oriented way of equalising the wealth in both states of nature (with and without flooding) would be to restrict governmental relief to an amount $\left(\mathrm{L}^{*}\right)$ reflecting an efficient level of precaution $\left(\mathrm{X}^{*}\right)$ or, in legal terms, making governmental aid conditional upon "reasonable" efforts by private households to selfprotect. In order to implement such "incentive-oriented" policies as a means of economically motivating precaution, the regulator needs some empirical estimates of the costs and benefits of private precaution. Benefit-cost ratios of private precautionary measures generally also come into play when banks are involved in the financing of any such measures.

\subsection{Benefit from precautionary measures}

Precautionary measures applied to private homes are believed to be effective mainly in areas with frequent, smallscale floods (ICPR, 2002). However, many precautionary building measures significantly reduced the flood damage even during the extreme flood event of August 2002 in the Elbe catchment (Kreibich et al., 2005).

\subsubsection{Building without a cellar}

Constructing a single-family house without a cellar may be an efficient precautionary measure in flood-prone areas, as buildings without cellars are generally damaged less by flooding. Such homes suffer no damages when homes with cellars are affected by low flood water. Thus, the average building damages of $14382 €$ and the average contents damages of $9091 €$ of single-family houses with cellars could be avoided completely in these cases (Fig. 2). In cases with higher levels of flood water, where the ground floors were additionally affected, the building and content damages 

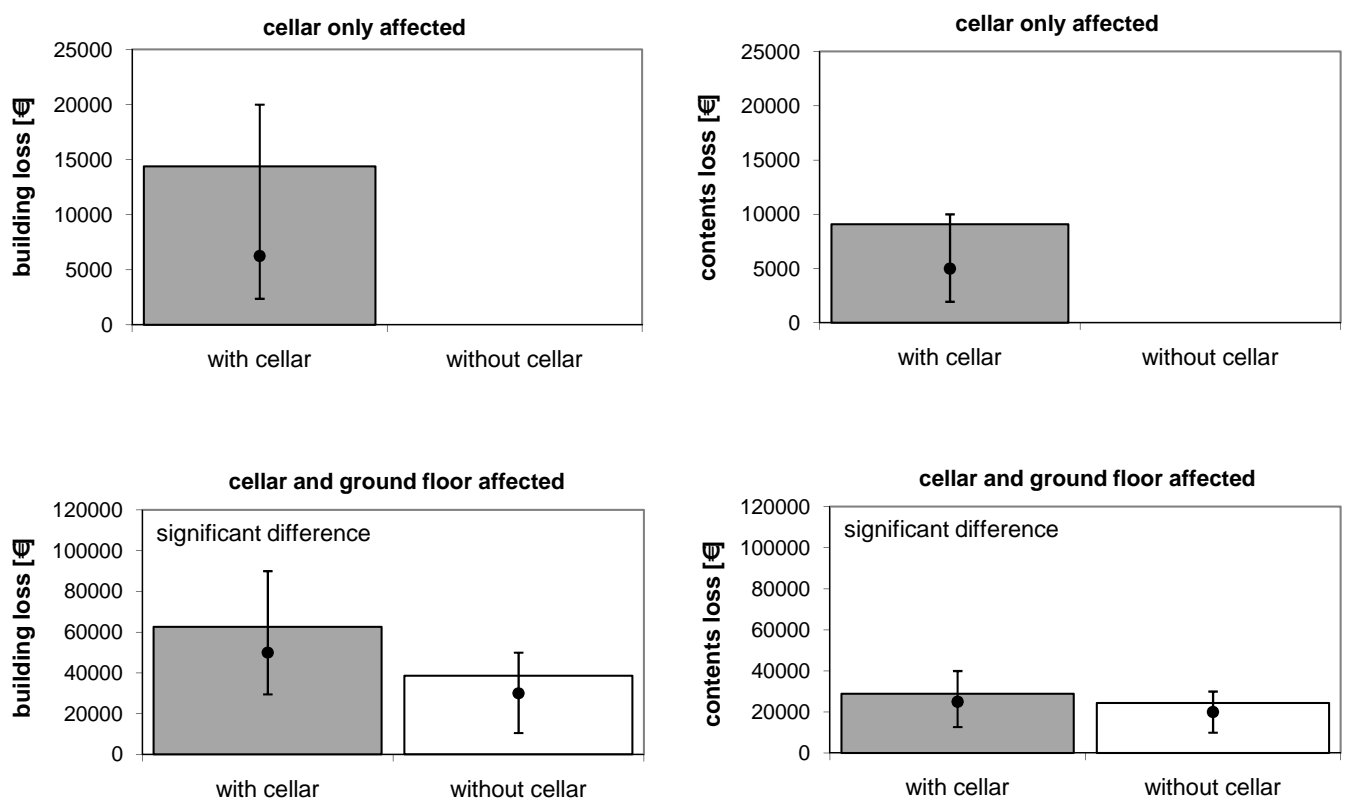

Fig. 2. Differences in building and contents damages between buildings with or without cellars, separated into cases where only cellars were affected and cases where ground floors also were affected (bars = means, points $=$ medians and $25-75 \%$ percentiles, significant differences between the cases with/without cellar are indicated).

were also significantly reduced on average by $23904 €$ and by $4419 €$, respectively, where the single-family houses were constructed without a cellar compared with the ones with a cellar. The ICPR (2002) states that building without a cellar can reduce flood damage in the residential sector in Germany by between $3000 €$ and $6000 €$. A study conducted after the extreme flooding in 2002 reported a significant average reduction of the damage ratios for buildings by $24 \%$ and for contents by $22 \%$ in cases where only the ground floor was affected in comparison with additional cellar damage (Kreibich et al., 2005).

\subsubsection{Adapting the building structure}

The precautionary measure of building flood-proof adaptations into the structure includes, for example, the construction of an especially stable foundation or of waterproof, sealed cellar walls with sealed piping. Unfortunately, no separate information about these different methods was acquired in the survey. One can only assume that the buildings fitted with flood-proof adaptations that still suffered losses in the cellar (when only the cellar was affected) probably had a stable foundation but no waterproof, sealed cellar. However, waterproofed tanking can also fail, or else water can enter through unprotected cellar windows or unsealed openings for utility pipes.

This measure showed a significant reduction in building damage: by $5956 €$ on average if only the cellar was affected, and by $20473 €$ if the ground floor was affected as well (Fig. 3). No significant contents damage reduction was achieved. Kreibich et al. (2005) also reported no impact on contents damage from this measure but a mean reduction of the building damage ratio by $24 \%$. In fact, in areas with great flood depth, this measure can be applied only to a limited extent, as the risk of buoyancy (or lifting force) of the flood water must be taken into account (Kelman and Spence, 2003; Kreibich and Thieken, 2008). If flood waters rise to high levels and the building is not protected against buoyancy, the cellar must be partly or entirely flooded with clean water in order to ensure stability. Thus the ICPR (2002) reports a damage reduction potential of between $75 \%$ and $85 \%$ of such structural building measures, albeit always dependent on the need to flood the cellar with clean water to preserve stability.

\subsubsection{Water barriers}

Domestic flood water barriers such as sandbags, mobile flood walls and sealants for doors and windows are only effective if they are able to withstand high water levels and if their impact is not negated by permeable cellar walls or openings for utility pipes. It is not surprising then, that in the cases where only cellars were affected, flood barriers showed no significant effect (Fig. 4). In the cases where ground floors were additionally affected, flood water barriers led to a significant average reduction in building damages of $23491 €$. However, there was no significant impact on contents damages (Fig. 4). The ICPR (2002) states that if the flood water does not flow over the water barriers, damage is potentially reduced by $60-80 \%$. The remaining 

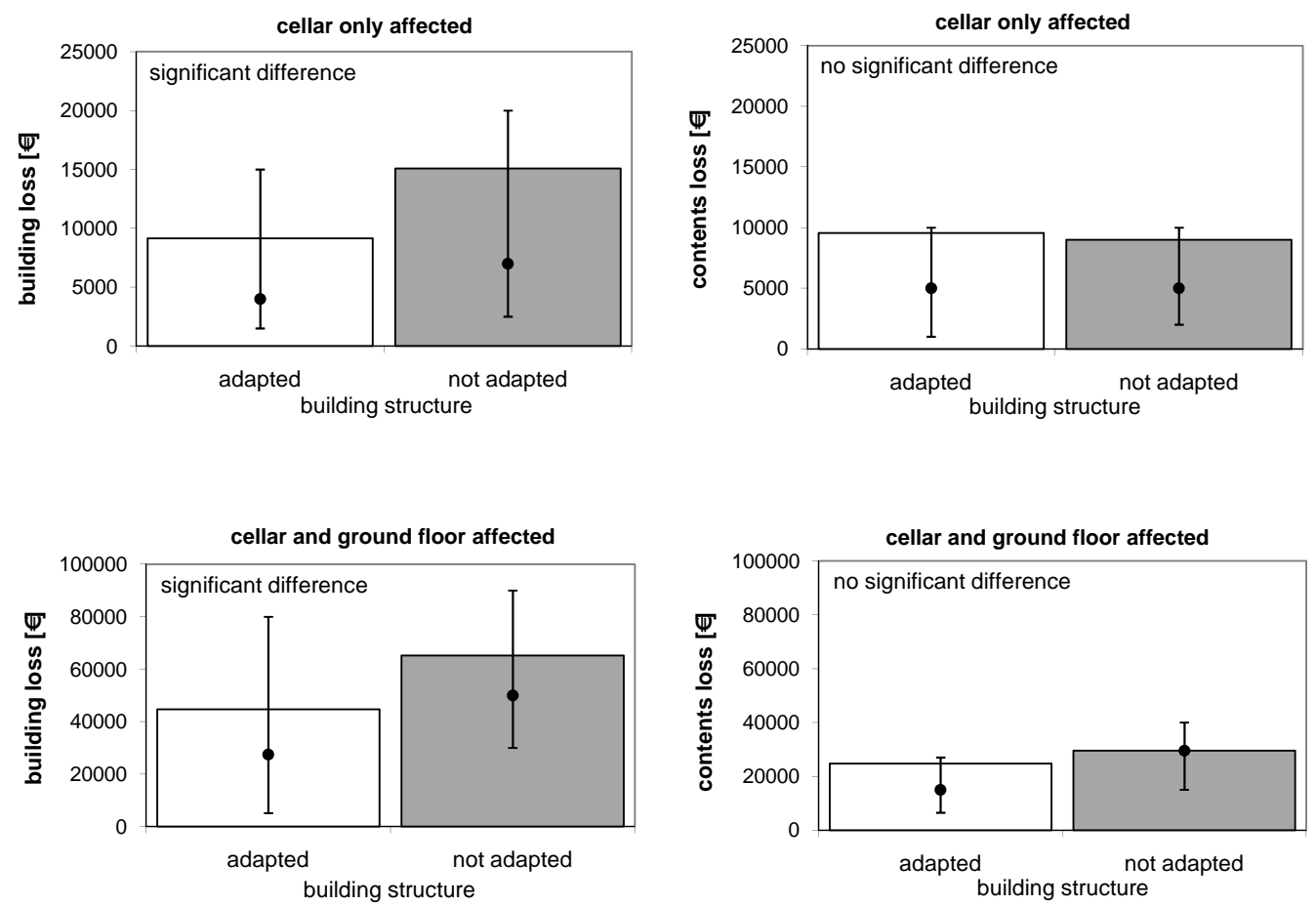

Fig. 3. The influence of flood adapted building structure on building and contents damages, separated into cases where only cellars were affected and cases where ground floors were affected as well (bars = means, points $=$ medians and $25-75 \%$ percentiles, significant differences between the cases with/without adapted building structure are indicated).
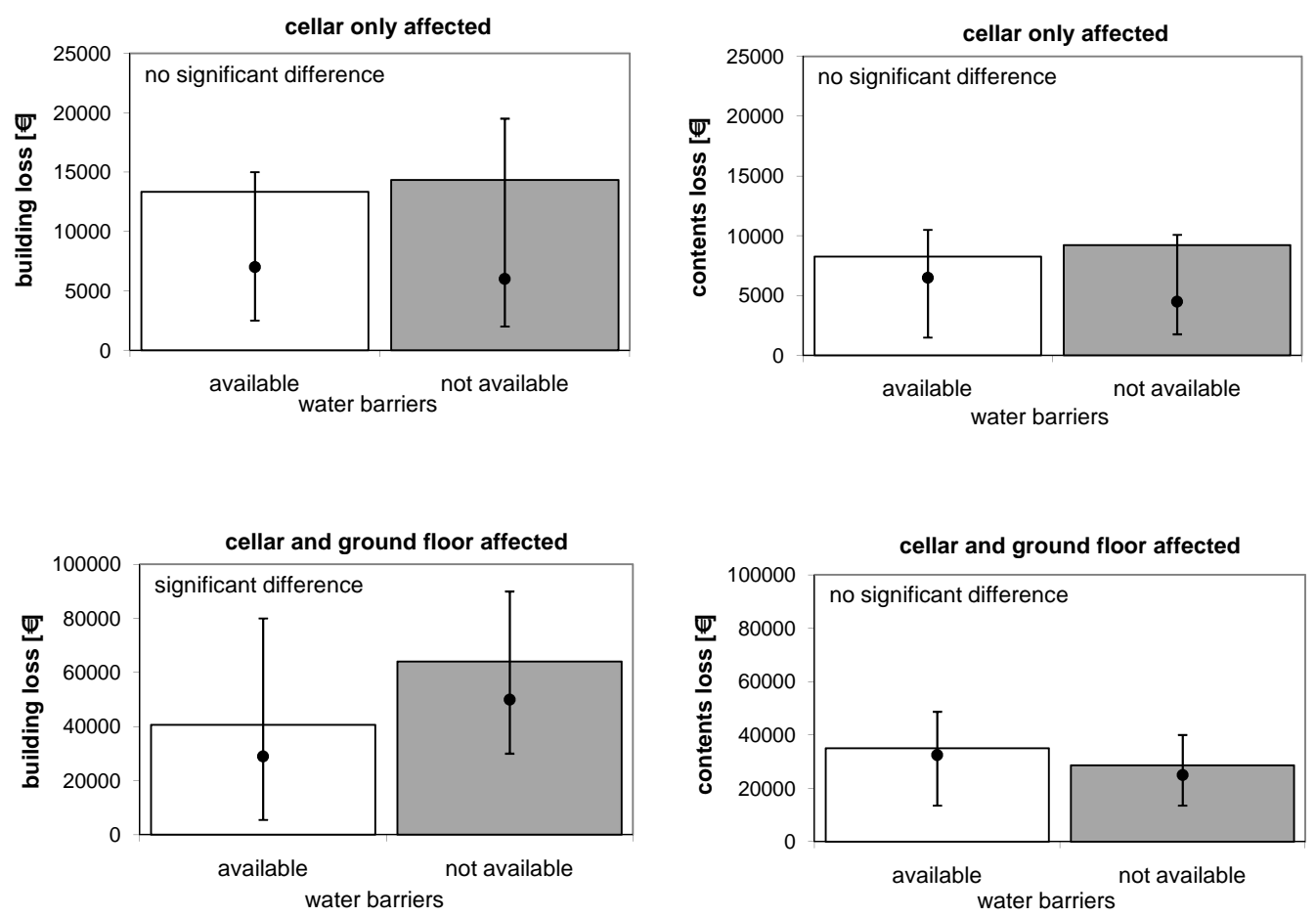

Fig. 4. The influence of water barriers on building and contents damages, separated into cases where only cellars were affected and cases where ground floors were affected as well (bars $=$ means, points = medians and $25-75 \%$ percentiles, significant differences between the cases with/without water barriers are indicated). 
damage depends mainly on the damage potential of cellars and whether or not cellar walls are sealed and waterproofed (ICPR, 2002). During the extreme flood event of 2002, many of the water barriers that had been erected were overwhelmed by the flood waters and, thus, had little to no effect. Still, during this flood the damage ratio of buildings was reduced on average by $29 \%$ for the cases where water barriers were in place (Kreibich et al., 2005).

\subsubsection{Prevent oil contamination}

In the cases where no oil contamination occurred, building damages were significantly lower on average: by $10482 €$ if only cellars were affected and by $26447 €$ if ground floors were affected as well (Fig. 5). Surprisingly, contents damage was significantly reduced, by an average of $4984 €$, only if cellars alone were affected (Fig. 5). Generally speaking, oil contamination can cause damage to buildings that is three times as great on average as without contamination and in particular cases it can even lead to total damage (Egli, 2002). For example, during the Whitsun flood of May 1999 in the region of Kelheim, Bavaria in the south of Germany, the mean damage to buildings amounted to $15622 €$. In cases where there was additional oil contamination, the mean damage increased to $52886 €$ (Deutsche Rückversicherung, 1999). As oil contamination is not confined to those buildings where a domestic oil tank collapses or leaks, but may also cause damage to other properties, oil tanks in flood risk-areas should be flood-proofed even if the individual costbenefit ratios are below one.

\subsection{Cost-benefit of precautionary measures}

\subsubsection{Building without a cellar}

Building a (flood-proofed) cellar is generally cost-intensive (as detailed in the next section). Thus, it seems reasonable to construct buildings without a cellar in flood-prone areas, particularly since buildings without cellars are also less expensive to construct.

The costs of living without a cellar depend mainly on the availability of alternative storage area. If there is enough storage area in higher storeys, e.g., the attic, no costs are incurred by this measure. In this case, building houses without a cellar is always economically efficient, since only benefits result (mitigated flood damages (Fig. 2), perhaps lower construction costs). If alternative storage area needs to be rented elsewhere due to a lack of space, opportunity costs are incurred. Average rental prices for floor space provide an estimate of these opportunity costs. Rental prices for floor space are between 3 and $4 € \mathrm{~m}^{-2}$ (IHK Dresden, 2009) depending on the location in the federal state of Saxony in Germany. Since having "a cellar in one's own house" can be equated with being in a particularly attractive location, the upper limit of $4 € \mathrm{~m}^{-2}$ is taken here. Thus, for a storage area of $65 \mathrm{~m}^{2}$ the alternative costs amount to $3120 €$ a year. Since these costs are expenses incurred annually, interest charges do not need to be considered.

Benefit-cost ratios are shown in Table 3. The construction of residential buildings without a cellar and renting alternative storage space is an efficient precautionary measure in high risk areas which are flooded once a year. However, in the long run, it is more expensive than having waterproofed, sealed cellar walls when a low interest rate $(\leq 3 \%)$ applies (Table 4). In lower risk areas it is more expensive to rent alternative storage space than to accept the risk of rare flood damages in the cellar (Table 3).

\subsubsection{Waterproofed, sealed cellar walls - adapting the building structure}

There are two common methods for waterproofing cellar walls: (a) constructions with a waterproof skin (bitumen sealing); (b) waterproof concrete with concrete slabs and waterproof interstices. Both have an average lifetime of about 75 years based on expert judgement (city of Vienna, personal communication, 2008), depending on the load. Building a waterproofed cellar using a construction with a waterproof skin (bitumen sealing) costs $465.10 € \mathrm{~m}^{-2}$, according to the construction bids tendered (Alpine Bau, personal communication). These costs need to be reduced by the costs which arise anyway (that is, if a "normal", not specifically waterproofed cellar is built): i.e., $465.10 € \mathrm{~m}^{-2}$ minus $180 € \mathrm{~m}^{-2}$, resulting in difference costs of $285.10 € \mathrm{~m}^{-2}$. Multiplying this figure by the $65 \mathrm{~m}^{2}$ of cellar floor gives rise to total costs for flood-proofing cellar walls of $18531.50 €$. Given an average lifetime of 75 years, annual costs are $4681.12 €$ or $2268 €$, depending on the choice of interest rate of $4 \%$ or $3 \%$, respectively.

Building a cellar using waterproof concrete with concrete slabs and waterproof interstices costs $505.00 € \mathrm{~m}^{-2}$. Deducting the costs which arise anyway if a "normal" cellar is built, the calculation is $505.35 € \mathrm{~m}^{-2}-180.00 € \mathrm{~m}^{-2}=$ $325.35 € \mathrm{~m}^{-2}$. For a cellar area of $65 \mathrm{~m}^{2}$ this results in total costs of $21147.75 €$. Given an average lifetime of 75 years, annual costs are $5341.99 €$ or $2588.18 €$, depending on the choice of interest rate of $4 \%$ or $3 \%$, respectively.

The average benefit per flood event of building structure adaptations, e.g., waterproof, sealed cellar walls by tanking is $5956 €$ if only the cellar is affected, and $20473 €$ if both the cellar and ground floor are affected (Fig. 3).

The resulting benefit-cost ratios for the two different constructions possible for waterproofed cellar tanking are shown in Table 4 for two different water depths and three different hazard zones (flood frequencies). For both constructions, benefit-cost ratios are above one only for frequent flooding once a year, regardless of the interest rate selected. 
Table 3. Benefit-cost ratios for the construction of residential buildings without a cellar.

\begin{tabular}{lccc}
\hline Cellar only affected & $\begin{array}{c}\text { Opportunity costs: } \\
\text { annual rental prices }\end{array}$ & $\begin{array}{r}\text { Benefit per year } \\
\text { (see Fig. 2) }\end{array}$ & Benefit-cost ratio \\
\hline Affected once a year & $3120 €$ & $23473 €$ & 7.52 \\
Affected once in 10 years & $3120 €$ & $2347 €$ & 0.75 \\
Affected once in 50 years & $3120 €$ & $469 €$ & 0.15 \\
\hline Cellar and ground floor affected & & & \\
\hline Affected once a year & $3120 €$ & $28323 €$ & 9.08 \\
Affected once in 10 years & $3120 €$ & $2832 €$ & 0.91 \\
Affected once in 50 years & $3120 €$ & $566 €$ & 0.18 \\
\hline
\end{tabular}

Table 4. Benefit-cost ratios for the construction of waterproof, sealed cellar walls using tanking: (a) constructions with a waterproof skin (bitumen sealing); (b) waterproof concrete tanking with concrete tanked slab and waterproof interstices.

\begin{tabular}{lcccccc}
\hline & \multicolumn{2}{c}{ Costs per year } & Benefit per year & \multicolumn{2}{c}{ Benefit-cost ratio } \\
\cline { 2 - 3 } \cline { 5 - 6 } & i.r.* $4 \%$ & i.r. 3\% & (see Fig. 3) & i.r. 4\% & i.r. 3\% \\
\hline (a) waterproof skin (bitumen sealing) & - cellar only affected & & \\
\hline Affected once a year & $4681 €$ & $2268 €$ & $5956 €$ & 1.27 & 2.63 \\
Affected once in 10 years & $4681 €$ & $2268 €$ & $596 €$ & 0.13 & 0.26 \\
Affected once in 50 years & $4681 €$ & $2268 €$ & $119 €$ & 0.03 & 0.05 \\
\hline (a) waterproof skin (bitumen sealing) & cellar and ground floor affected & \\
\hline Affected once a year & $4681 €$ & $2268 €$ & $20473 €$ & 4.37 & 9.03 \\
Affected once in 10 years & $4681 €$ & $2268 €$ & $2047 €$ & 0.44 & 0.90 \\
Affected once in 50 years & $4681 €$ & $2268 €$ & $410 €$ & 0.09 & 0.18 \\
\hline (b) concrete tanked slab and waterproof interstices & - cellar only affected & \\
\hline Affected once a year & $5342 €$ & $2588 €$ & $5956 €$ & 1.11 & 2.30 \\
Affected once in 10 years & $5342 €$ & $2588 €$ & $596 €$ & 0.11 & 0.23 \\
Affected once in 50 years & $5342 €$ & $2588 €$ & $119 €$ & 0.02 & 0.05 \\
\hline (b) concrete tanked slab and waterproof interstices - cellar and ground floor affected \\
\hline Affected once a year & $5342 €$ & $2588 €$ & $20473 €$ & 3.83 & 7.91 \\
Affected once in 10 years & $5342 €$ & $2588 €$ & $2047 €$ & 0.38 & 0.79 \\
Affected once in 50 years & $5342 €$ & $2588 €$ & $410 €$ & 0.08 & 0.16 \\
\hline
\end{tabular}

* i.r. $=$ interest rate

\subsubsection{Mobile flood water barriers}

Mobile water barriers are used in a similar way to sandbags to prevent the intrusion of surface water during flooding. They are especially advantageous, since they are only used when necessary and are reusable. Purchasing a mobile barrier $1 \mathrm{~m}$ in height, including the necessary support, costs $610 €$ per $\mathrm{m}$ (www.hochwasserschutz.de). Given an average lifetime of 20 years, annual costs of either $66.80 €$ or $55.10 €$ per running metre arise, depending on the choice of interest rate of $4 \%$ or $3 \%$, respectively. For an average "model property" of $750 \mathrm{~m}^{2}, 10 \mathrm{~m}$ of property length are estimated to be adjacent to a river. Since mobile water barriers protect against surface water only and are efficient only if their impact is not negated by the presence of permeable cellar walls, it is hardly surprising that they are only economically efficient if the cellar and ground floor are affected by flooding (Table 5). Cost-benefit ratios are positive (above one) for flood frequencies of once in 10 years or more often. 

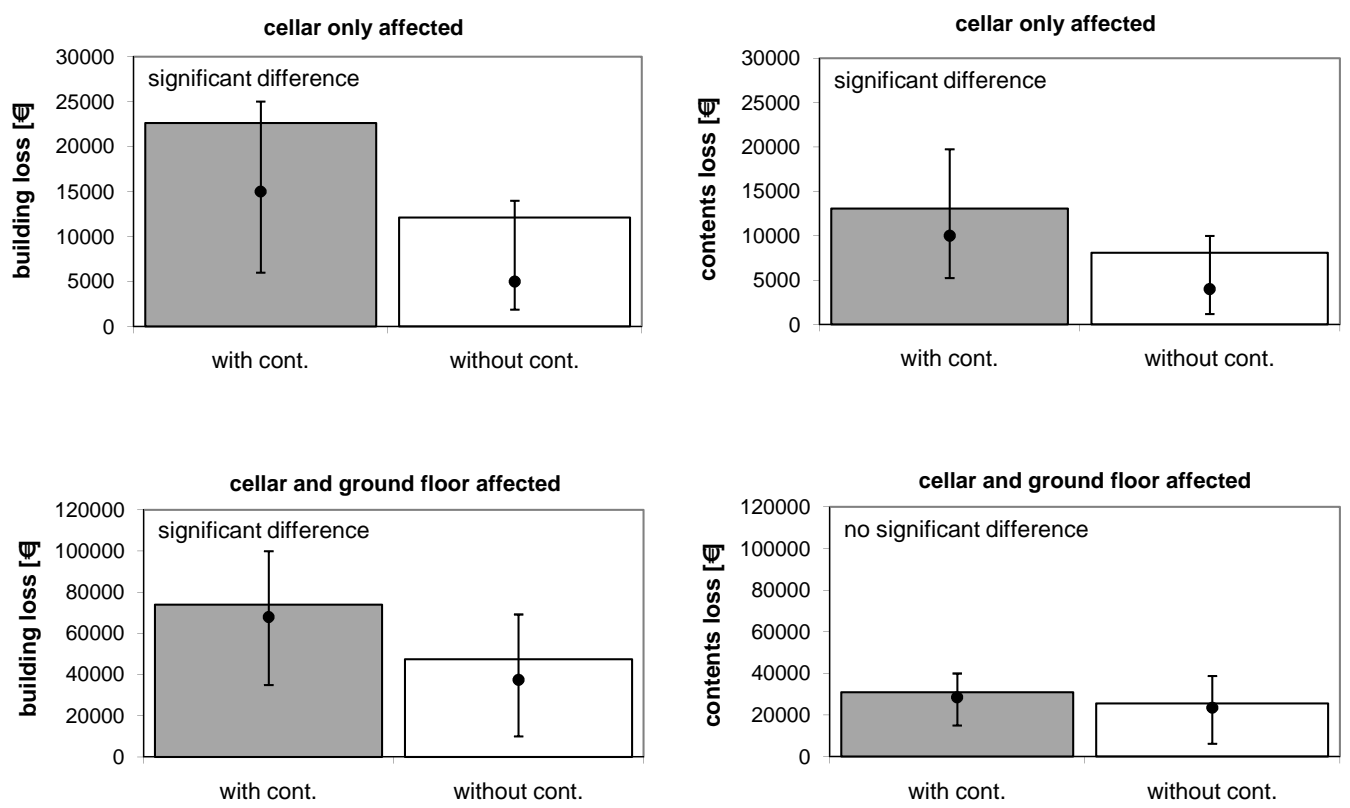

Fig. 5. The influence of oil contamination on building and contents damages, separated into cases where only cellars were affected and cases where ground floors were affected as well (bars = means, points $=$ medians and $25-75 \%$ percentiles, significant differences between the cases with/without contamination are indicated).

Table 5. Benefit-cost ratios for mobile water barriers.

\begin{tabular}{lrrrrrr}
\hline Cellar and ground floor affected & \multicolumn{2}{c}{ Costs per year } & \multirow{2}{*}{ Benefit per year } & \multicolumn{2}{c}{ Benefit-cost ratio } \\
\cline { 2 - 3 } \cline { 7 - 7 } & i.r.* $4 \%$ & i.r. 3\% & (see Fig. 4) & i.r. 4\% & i.r. 3\% \\
\hline Affected once a year & $668 €$ & $551 €$ & $23491 €$ & 35.17 & 42.63 \\
Affected once in 10 years & $668 €$ & $551 €$ & $2349 €$ & 3.52 & 4.26 \\
Affected once in 50 years & $668 €$ & $551 €$ & $470 €$ & 0.70 & 0.85 \\
\hline
\end{tabular}

$*$ i.r. $=$ interest rate

\subsubsection{Preventing oil contamination by securing oil tanks}

Oil tanks should be secured in all flood risk areas, not only because of the potential economic damages to buildings and other assets but also due to the risk of ecological damage. The costs of doing so are $1009 €$ for a floodproofed oil tank with a volume of 1500 litres which is secured against buoyancy (Fachgemeinschaft Ölwärme \& Service, 2008). Given an average lifetime of an oil tank of 30 years (Fachgemeinschaft Ölwärme \& Service, 2008), annual costs arising are roughly either $109 €$ or $82 €$ depending on the interest rate selected of $4 \%$ or $3 \%$, respectively. Securing oil tanks is a measure that consistently shows a positive benefitcost ratio above one (Table 6), in contrast to large, expensive construction measures such as waterproofing cellar walls by tanking (Table 4).

\section{Conclusions}

The rise in flood damages calls for significantly improved flood risk management and greater self-reliance on the part of private households, including greater involvement in mitigation measures. Economically "reasonable" efforts to self-insure and self-protect can be expected from households in the face of rising damages, alongside increased protection by public authorities and governmental relief programmes. This study has looked at the efficiency of selected precautionary measures taken by private households against floods. To summarise the findings: large investments, e.g., waterproofed cellars, are economically "reasonable" if the building is located in a high risk area. Small investments, e.g., securing oil tanks, are economically "reasonable", even if the building is flooded only once every 50 years. The policy-related conclusions arising from these 
Table 6. Benefit-cost ratios for securing oil tanks.

\begin{tabular}{lccrrrr}
\hline & \multicolumn{2}{c}{ Costs per year } & Benefit per year & \multicolumn{2}{c}{ Benefit-cost ratio } \\
\cline { 2 - 3 } & i.r. $4 \%$ & i.r. 3\% & (see Fig. 5) & i.r. 4\% & i.r. 3\% \\
\hline \multicolumn{7}{c}{ Cellar only affected } \\
\hline Affected once a year & $109 €$ & $82 €$ & $15466 €$ & 141.89 & 188.61 \\
Affected once in 10 years & $109 €$ & $82 €$ & $1547 €$ & 14.19 & 18.87 \\
Affected once in 50 years & $109 €$ & $82 €$ & $309 €$ & 2.83 & 3.77 \\
\hline & Cellar and ground floor affected & & \\
\hline Affected once a year & $109 €$ & $82 €$ & $26447 €$ & 242.63 & 322.52 \\
Affected once in 10 years & $109 €$ & $82 €$ & $2645 €$ & 24.27 & 32.26 \\
Affected once in 50 years & $109 €$ & $82 €$ & $529 €$ & 4.85 & 6.45 \\
\hline
\end{tabular}

* i.r. $=$ interest rate.

findings are that legislation should be in place to prevent the construction of buildings in flood risk areas and should make "reasonable" precautionary measures mandatory for people already living in such areas. The motivation of private households to take such measures could be enhanced via financial incentives, e.g., by making governmental assistance for damages conditional upon "reasonable" precautions, or by reducing premiums as a part of home insurance contracts (Holub and Fuchs, 2009). Finally, it appears reasonable to speculate that as the costs of commonly applied measures fall due to mass production, more precautionary measures will become economically efficient.

Acknowledgements. This research was undertaken partly within the framework of the MEDIS project (Methods for the Evaluation of Direct and Indirect Flood Losses), funded by the German Ministry of Education and Research (BMBF) (No. 0330688) and partly within the framework of the "Climate-proof flood risk management" project supported by the Dutch research programme Knowledge for Climate (Theme 1). The survey in 2006 was also undertaken as part of the MEDIS project. The survey after the 2002 flood was undertaken under the auspices of the German Research Network Natural Disasters (DFNK) and was funded by Deutsche Rückversicherung AG and BMBF (No. 01SFR9969/5). The survey in the city of Dresden was conducted within the MULTISURE project (Entwicklung multisequenzieller Vorsorgestrategien für grundhochwassergefährdete urbane Lebensräume), funded by BMBF (No. 0330755).

Edited by: L. Ferraris

Reviewed by: S. Fuchs and another anonymous referee

\section{References}

ABI (Association of British Insurers): Assessment of the cost and effect on future claims of installing flood damage resistant measures, ABI, London, UK, 2003.

Barredo, J. I.: Normalised flood losses in Europe: 1970-2006, Nat. Hazards Earth Syst. Sci., 9, 97-104, doi:10.5194/nhess-997-2009, 2009.

BMVBW (Bundesministerium für Verkehr-, Bau- und Wohnungswesen): Hochwasserschutzfibel - Planen und Bauen von Gebäuden in hochwassergefährdeten Gebieten, BMVBW, Berlin, Germany, 2002 (in German).

Borchert, J.: Flusskorridore als überregionale Verbundstrukturen, Natur und Landschaft, 67(9), 413-418, 1992 (in German).

Botzen, W. J. W., Aerts, J. C. J. H., and van den Bergh, J. C. J. M.: Willingness of homeowners to mitigate climate risk through insurance, Ecol. Econ., 68, 2265-2277, 2009.

Bowker, P.: Making properties more resistant to floods, Municipal Engineer, 151(3), 197-205, 2002.

Crichton, D.: Role of Insurance in Reducing Flood Risk, The Geneva Papers, 32, 117-132, 2008.

Department of Human Services: Assessing Resilience and Vulnerability in the Context of Emergencies: Guidelines, Victorian Government Publishing Service, 2000.

Deutsche Rückversicherung: Das Pfingsthochwasser im Mai 1999, Deutsche Rückversicherung, Düsseldorf, Germany, 1999 (in German).

Egli, T.: Hochwasserkatastrophe Ostdeutschland 2002 - Erkenntnisse in Bezug auf Gebäudeschäden, Berichtüber die Abklärungsmission der Direktion für Entwicklung und Zusammenarbeit (DEZA, Abt. Humanitäre Hilfe und Schweizer Katastrophenhilfekorps) im Katastrophengebiet des Hochwassers der Elbe und ihrer Seitenflüsse vom 23-30 August 2002, Vereinigung Kantonaler Feuerversicherungen, St. Gallen, Switzerland, 2002 (in German).

Ehrlich, I. and Becker, G.: Market Insurance, Self-Insurance, and Self-Protection, J. Polit. Econ., 80, 623-648, 1972.

Environment Agency: Damage Limitation, How to make your home flood resistant, Bristol, UK, 2003a. 
Environment Agency: Flood Products. Using flood protection products - A guide for homeowners, Bristol, UK, 2003b.

Fachgemeinschaft Ölwärme \& Service: Sichere Heizöllagerung im Überschwemmungsgebiet, Rosenheim, Germany, available at: http://www.chiemin.de/Eigene-Dateien/Heizungsdienst/ HochwasserFlyer.pdf (last access: 23September 2010), 2008 (in German).

FEMA (Federal Emergency Management Agency): Homeowner's guide to retrofitting - Six ways to protect your house from flooding, FEMA Publications, Washington, DC, USA, 1998a.

FEMA (Federal Emergency Management Agency): Repairing your flooded home, FEMA Publications, Washington, DC, USA, 1998b.

Feyen, L., Barredo, J. I., and Dankers, R.: Implications of global warming and urban land use change on flooding in Europe, in: Water and urban development paradigms, edited by: Feyen, J., Shannon, K., and Neville, M., Taylor \& Francis Group, London, UK, 217-225, 2009.

Grothmann, T. and Reusswig, F.: People at risk of flooding: Why some residents take precautionary action while others do not, Nat. Hazards, 38(1-2), 101-120 2006

Hall, J. W., Evans, E. P., Penning-Rowsell, E. C., Sayers, P. B., Thorne, C. R., and Saul, A. J.: Quantified scenarios analysis of drivers and impacts of changing flood risk in England and Wales: 2030-2100, Environmental Hazards, 5, 51-65, 2003.

Hall, J. W., Sayers, P. B., and Dawson, R. J.: National-scale Assessment of Current and Future Flood Risk in England and Wales, Nat. Hazards, 36, 147-164, 2005.

Hayes, B. D.: Interdisciplinary planning of non-structural flood hazard mitigation, J. Water Res. Pl.-ASCE, 130, 15-25, 2004.

Heiland, P.: Vorsorgender Hochwasserschutz durch Raumplanung, interregionale Kooperation und ökonomischen Lastenausgleich, Schriftenreihe WAR 143, Technische Universität Darmstadt, Darmstadt, Grermany, 2002 (in German).

Holub, M. and Fuchs, S.: Mitigating mountain hazards in Austria legislation, risk transfer, and awareness building, Nat. Hazards Earth Syst. Sci., 9, 523-537, doi:10.5194/nhess-9-523-2009, 2009.

Holub, M. and Hübl, J.: Local protection against mountain hazards - state of the art and future needs, Nat. Hazards Earth Syst. Sci., 8, 81-99, doi:10.5194/nhess-8-81-2008, 2008.

ICPR (International Commission for the Protection of the Rhine): Non structural flood plain management - measures and their effectiveness, ICPR, Koblenz, Germany, 2002.

IHK Dresden (Industrie- und Handelskammer Dresden): Gewerbemieten im Kammerbezirk Dresden, Germany, available at: http://www.dresden.ihk.de/servlet/link_file?link_id=9146 \&publ_id=49 \\&ref_knoten_id=52312 $\backslash \&$ ref_detail=publikation $\backslash$ \&ref_sprache=deu (last access: 23 September 2010), 2009 (in German).

Kelman, I. and Spence, R.: A Limit Analysis of Unreinforced Masonry Failing Under Flood Water Pressures, Masonry International, 16(2), 51-61, 2003.

Kleindorfer, P. R. and Kunreuther, H.: The complementary roles of mitigation and insurance in managing catastrophic risks, Risk Anal., 19(4), 727-738, 1999.

Kreibich, H. and Thieken, A. H.: Assessment of damage caused by high groundwater inundation, Water Resour. Res., 44, W09409, doi:10.1029/2007WR006621, 2008.
Kreibich, H., Thieken, A. H., Petrow, Th., Müller, M., and Merz, B.: Flood loss reduction of private households due to building precautionary measures - lessons learned from the Elbe flood in August 2002, Nat. Hazards Earth Syst. Sci., 5, 117-126, doi:10.5194/nhess-5-117-2005, 2005.

Kreibich, H., Thieken, A. H., Grunenberg, H., Ullrich, K., and Sommer, T.: Extent, perception and mitigation of damage due to high groundwater levels in the city of Dresden, Germany, Nat. Hazards Earth Syst. Sci., 9, 1247-1258, doi:10.5194/nhess-91247-2009, 2009.

Kreibich, H., Seifert, I., Thieken, A. H., Lindquist, E., Wagner, K., and Merz, B.: Recent changes in flood preparedness of private households and businesses in Germany, Reg. Environ. Change, in press, doi:10.1007/s10113-010-0119-3, 2010.

Kron, W.: Zunehmende Überschwemmungsschäden: Eine Gefahr für die Versicherungswirtschaft? ATV-DVWK, Bundestagung 15.-16.09.2004 in Würzburg, DCM, Meckenheim, Germany, 47-63, 2004 (in German).

Kundzewicz, Z. W., Ulbrich, U., Brücher, T., Graczyk, D., Krüger, A., Leckebusch, G. C., Menzel, L., Pinskwar, I., Radziejewski, M., and Szwed, M.: Summer floods in Central Europe - climate change track?, Nat. Hazards, 36, 165-189, 2005.

LfU Bayern (Bayerisches Landesamt für Umwelt): Endbericht Hochwasser August 2005 - August-Hochwasser 2005 in Südbayern, LfU Bayern, Augsburg, Germany, 2006 (in German).

Merz, B. and Thieken, A. H.: Flood Risk Analysis: Concepts and Challenges, ÖWAW, 56(3-4), 27-34, 2004.

Mudelsee, M., Börngen, M., Tetzlaff, G., and Grünewald, U.: No upward trends in the occurrence of extreme floods in central Europe, Nature, 425, 166-169, 2003.

Mudelsee, M., Börngen, M., Tetzlaff, G., and Grünewald, U.: Extreme floods in Central Europe over the past 500 years: role of cyclone pathway "Zugstrasse Vb", J. Geophys. Res., 109, D23101, doi:10.1029/2004JD005034, 2004.

Munich Re: NatCatSERVICE, available at: www.munichre.com (last access: 20 November 2009), 2009.

MURL (Ministerium für Umwelt, Raumordnung und Landwirtschaft des Landes Nordrhein-Westfalen): Hochwasserfibel - Bauvorsorge in hochwassergefährdeten Gebieten, MURL, Düsseldorf, Germany, 2000 (in German).

Petrow, T. and Merz, B.: Trends in flood magnitude, frequency and seasonality in Germany in the period 1951-2002, J. Hydrol., 371, 129-141, 2009.

Raschky, P. A.: Institutions and the losses from natural disasters, Nat. Hazards Earth Syst. Sci., 8, 627-634, doi:10.5194/nhess-8627-2008, 2008.

Reeve, D. and Badr, A.: Performance of sandbags for domestic flood defence, P. I. CIVIL Eng.-Water, 156(4), 341-349, 2003.

Schreider, S. Yu., Smith, D. I., and Jakeman, A. J.: Climate Change Impacts on Urban Flooding, Climatic Change, 47, 91-115, 2000.

Siegrist, M. and Gutscher, H.: Flooding risks: a comparison of lay people's perceptions and expert's assessments in Switzerland, Risk Anal., 26(4), 971-979, 2006.

Siegrist, M. and Gutscher, H.: Natural hazards and motivation for mitigation behaviour: People cannot predict the affect evoked by a severe flood, Risk Anal., 28(3), 771-778, 2008.

Smith, D. I.: Actual and potential flood damage: a case study for urban Lismore, NSW, Australia, Appl. Geogr., 1, 31-39, 1981. 
Smith, D. I.: Urban Flood Damage and Greenhouse Scenarios - The Implications for Policy: An Example from Australia, Mitigation and Adaptation Strategies for Global Change, 4, 331-342, 1999.

Svensson, C., Hannaford, J., Kundzewicz, Z. W., and Marsh, T. J.: Trends in river floods: why is there no clear signal in observations?, in: Frontiers in Flood Research, edited by: Tchiguirinskaia, I., Thein, N. N. K., and Hubert, P., IAHS Pub., 305, 1-18, 2006.

Thieken, A. H., Müller, M., Kreibich, H., and Merz, B.: Flood damage and influencing factors: new insights from the August 2002 flood in Germany, Water Resour. Res., 41, W12430, doi:10.1029/2005WR004177, 2005.

Thieken, A. H, Kreibich, H., Müller, M., and Merz, B.: Coping with floods: preparedness, response, recovery of flood-affected residents in Germany in 2002, Hydrolog. Sci. J., 52(5), 10161037, 2007.

Thywissen, K.: Components of Risk - A comparative Glossary, SOURCE, 2, 52 pp., 2006.

UNDP (United Nations Development Programme) Bureau for Crisis Prevention and Recovery: Reducing Disaster Risk: A Challenge for Development, in: A Global Report, edited by: Pelling, M., Maskrey, A., Ruiz, P., and Hall, L., John S. Swift Co., USA, 146 pp., 2004.
USACE (U.S. Army Corps of Engineers): Flood Proofing, Washington, DC, EP:1165-2-314, 1995.

USACE (U.S. Army Corps of Engineers): Engineering and Design. Risk-Based analysis for flood damage reduction studies, Washington, DC, Manual No. 1110-2-1619, 1996.

VAwS-Baden-Württemberg: Verordnung des Ministeriums für Umwelt und Verkehr über Anlagen zum Umgang mit wassergefährdenden Stoffen und über Fachbetriebe, Anlagenverordnung Wassergefährdende Stoffe - VawS, BadenWürttemberg, Germany, 2005 (in German).

VAwS-Bayern: Verordnung über Anlagen zum Umgang mit wassergefährdenden Stoffen und über Fachbetriebe, Anlagenverordnung-VAwS, Bayern, Germany, 2008 (in German).

VAwS-Hessen: Verordnung über Anlagen zum Umgang mit wassergefährdenden Stoffen und über Fachbetriebe, Anlagenverordnung-VAwS, Hessen, Germany, 2006 (in German).

Wind, H. G., Nierop, T. M., de Blois, C .J., and de Kok, J. L.: Analysis of flood damages from the 1993 and 1995 Meuse floods, Water Resour. Res., 35(11), 3459-3465, 1999.

Wynn, P.: Potential common law liability for privately provided flood defences, Structural Survey, 22, 110-113, 2004. 